\title{
Interrupter Device
}

National Cancer Institute

\section{Source}

National Cancer Institute. Interrupter Device. NCI Thesaurus. Code C50009.

A device designed to stop the flow of current in a circuit. 